study shows that clinical events, particularly mortality, are what matter when assessing the value of antiretroviral treatment.

B G GAZZARD

Clinical director

HIV/Genitourinary Medicine Unit, Chelsea and Westminster Hospital, London SW10 9NH

1 Aboulker JP, Swart AM. Preliminary analysis of the Concorde trial. Lancet 1993;341:889-90. 2 Dillner L. Doubts cast on zidovudine's use in delaying AIDS. $B M \mathcal{F}^{\prime}$ 1993;306:949-50.

3 Centers for Disease Control. Revision of the CDC surveillance case definition for acquired immunodeficiency syndrome. $M M W R$ 1987;36(suppl):1-15.

4 Fischl MA, Richmann DD, Grieco MH, Gottlieb MS, Volberding PA, Laskin OL, et al. The efficacy of 3-azido-3-deoxythymidine (aziothymidine) in the treatment of patients with AIDS and
AIDS-related complex: a double-blind placebo-controlled trial. N Engl f Med 1987;317:185-91 5 Schmitt FA, Bigley JW, McKinnis R, Logue PE, Evans RW, Drucker $I$, et al. Neurophysiologica outcome of zidovudine (AZT) treatment of patients with AIDS and AIDS-related complex. N Engl f Med 1988;319:1573-8.

6 Pantaleo G, Graziosl C, Demarest J, Butini L, Montroni M, Fox CH, et al. HIV infection is active and progressive in lymphoid tissue during the clinically latent stage of disease. Nature 1993;362: and progr.

Connor S. HIV is active even in latency. BMF 1993:306:949.

8 Tersmette M, Lange JMA, De Goede REY, de Wolf F, Eftink-Schattenkerk JKM, Schellckens PTA, et al. Association between biological properties of human immunodeficiency virus variants and risk for AIDS and AIDS mortality. Lancet 1989;i:983-5.

Richman DD, Grimes JM, Lagakos SW. Effect of stage of disease and drug dose on zidovudine susceptibilities of isolates of human immunodeficiency virus. Fournal of AIDS 1990;3:743-6.

10 Fischl MA, Richmann DD, Hansen N, Collier AC, Carey JT, Para MF, et al. The safety and efficacy of zidovudine (AZT) in the treatment of subjects with mildly symptomatic human Immunodeficiency virus type 1 (HIV) infection. Ann Intern Med 1990;112:727-37.

11 Volberding PA, Lagakos SW, Koch MA, Pettinelli C, Myers MW, Booth DK, et al. Zidovudine in asymptomatic human immunodeficiency infection-a controlled trial in persons with fewer than 500 CD4-positive cells per cubic millimeter. N Engl F Med 1990;322:941-9.

\title{
What's happening to health care in Germany?
}

\author{
More attempts to curb its costs
}

This year statutory health insurance in Germany celebrates its 110 th anniversary. Although health care is provided virtually free at the point of delivery, there are no queues except for transplants. Both hospital and ambulatory care takes place in technically well equipped settings, which are fairly evenly distributed to offer wide access to high quality care.'

When it was first introduced statutory health insurance was modelled on existing self help ("solidarity") groups based on professions. Sick pay was the main benefit of the fund, which was paid as a proportion of wage and was meant to cover loss of income related to disease. Health care was of minor importance and was provided only to restore ability to work. To a large extent the members of a fund had to decide on their fund's benefit policy, and a common interest existed in keeping contributions low. There was tight social control on use by other fund members. ${ }^{23}$

Today, solidarity means something quite different. It reflects the ideal that the entire population should have equal access to the complete range of health care irrespective of ability to pay. Statutory health insurance has become a means of achieving a social welfare policy based on the principle of redistribution.

Many politicians and scientists, however, consider both the present insurance system and the provision of care to be ineffective and inefficient. Financing through contributions related to income does not reflect individual risk. It is likely to lead to overuse of services, intentionally or unintentionally, which are free at the point of delivery but paid for collectively. This tendency, inherent in all systems of third party payment, is amplified by fee for service remuneration for ambulatory care. Employees' traditionally limited choice between statutory health insurers (partly due to the funds' membership being profession related) has been kept up while the benefits have been extended and standardised for all funds within statutory health insurance. Today, differences in premiums between funds largely reflect different risk factors for illness (such as income, sex, and age) among their members.

Although the proportion of gross national product spent on health has remained fairly constant at about $8 \%$ over the past 15 years, ${ }^{1}$ the spending per insured person has increased. Because financing of health care relies entirely on wage related contributions premiums steadily increased, reaching $13 \cdot 1 \%$ of incomes last October. In 1991 spending by statutory sickness funds grew more than twice as fast as wages, resulting in a deficit of DM5.5bn. ${ }^{4}$ The gap between these growth rates worsened last year, leading to an expected deficit of DM10bn. ${ }^{4}$ The government and Social Democrat opposi- tion agreed on a reform package last October, and the health structure act came into force on 1 January.

The new act introduces a system of compensation payments between the statutory insurance fund to minimise the effects of variations among the funds' different risk structures, thereby reducing difference in premiums. To this end the act also regulates further the contractual relations between funds' members and providers. Although the reformers claim to be generating equal conditions for competition between the funds before introducing unlimited choice between statutory health insurers, they have effectively standardised all activities of the funds. This opens up the prospect of a single national sickness fund in the near future.

The new act attempts to curb the rise in the costs of health care, which has continued despite a series of recent cost containment acts. A rigid budget will limit the growth of spending in all sectors-ambulatory, inpatient, and dental care and drugs and appliances - to the rate of growth of salaried incomes. As the state will enforce the budget this provides another step towards a state run standardised national insurance. The fixed budget for hospitals is mainly intended to reduce the average length of stay and number of beds. Reimbursement will change from the full costs of hospital charges to fixed premiums related to the diagnosis.

The proposed budget does not tackle the question of setting priorities. On the contrary, the reform is advertised as a way of making medical care cheaper while continuing to provide every possible service to everybody. By simply capping health care expenditure the resulting budget is not structured according to need-the budget simply freezes the relative weights of the sectors at the level that emerged historically under previous regulation. In future the federal government will decide a global resource allocation that has previously been the aggregate of many decentralised decisions.

Against the background of medical progress and an aging population limiting the growth of expenditure seems unlikely without some kind of rationing. This can happen either centrally through the setting of priorities or through individual denial of treatment by providers. Presently no legal base exists for providers to set priorities or to deny treatment within the existing catalogue of services. On the contrary, politicians keep extending entitlements to services, and medicolegal fears contribute to high diagnostic activity.

The time has come to reconsider what statutory health insurance is really for. One way forward is to limit statutory health insurance to providing a uniform package of basic services with insurance funds competing to provide additional 
services. Horst Seehofer, the minister of health, has already announced that statutory health insurance is in his sights. Redefining its scope is promised within the decade.

DOMINIK VON STILLFRIED

Health economist

Institute for Health Care Systems Research, MICHAEL ARNOLD

University of Tübingen, D-7400 Tübingen, Germany
1 Amold M. Health care in the Federal Republic of Gennany. Cologne: Deutscher Arzteverlag,

2 Leber W-D. Risikostrukturausgleich in der gesetzlichen Krankenversichenung. Baden-Baden: Nomos Verlagsgesellschaft, 1991:85-9.

3 Frevert U. Krankheit als politisches Problem 1770-1880. Göttingen: Vandenhoeck \& Ruprecht, 1984.

4 Gesetzentwurf der Bundesregierung. Entwurf eines Gesetzes zur Sicherung und Strukturverbesserung der gesetzlichen Krankenversicherung (Gesundheits-Strukturgesetz 1993). Bonn: House of Parliament, 1992. (Working paper 12/3209.)

\section{Reporting deaths to coroners}

\section{All the legal aspects of dying need re-examining}

Start and colleagues confirm the long held suspicion that knowledge of which deaths should be reported to the coroner is no better among senior doctors than it is among their juniors (p 1038). ' Embarrassingly, doctors in this analysis of fictitious case histories performed "only about half" as well as "experienced local coroners' staff." The fact that these lay officers rely on information supplied by doctors-whose awareness of what may be of medicolegal importance seems questionableis entirely congruent with other anomalies inherent in the law concerning the disposal of the dead. ${ }^{2}$

Even with a knowledge of the law greater than that offered to the average medical student, ${ }^{3}$ the precise legal duty placed on any doctor to report any death remains obscure. There is no statutory duty, and the common law duty referred to by Start and colleagues is that "of every person to give information which may lead to the coroner having notice of circumstances requiring the holding of an inquest." 4 The foundations of this common law duty are difficult to define: the case cited most often dates from 1702 and seems more concerned with the nature of the evidence required for a verdict of suicide. ${ }^{5}$ As noted by Polson and Marshall, the duty cannot be enforced unless the failure to report obstructs the coroner, ${ }^{6}$ and for such a charge to be proved it is necessary to prove intent to obstruct. ${ }^{7}$ It can hardly be argued that lack of knowledge constitutes intent; it might be argued that the common law duty is so nebulous as to be meaningless.

The "local rules" cited by Start and colleagues,' having no statutory force, may represent a coroner acting in excess of his jurisdiction. We would not consider that the death in their case 1 would need to be reported, despite the short period of admission, so long as the attending doctor felt able to state the cause of death "to the best of his knowledge and belief." ${ }^{\text {We }}$ realise that this may run counter to the conclusion of Brodrick that a primary function of the coroner "is to help to establish the cause of death" but, where the death is not both sudden and of unknown cause, we believe that the proper means of confirming a clinical diagnosis is a hospital postmortem examination.

What is less defensible-whether the clinical opinion of the cause of death is confirmed by a hospital postmortem examination or not-is the apparent inability of doctors to complete a death certificate accurately. In his recent analysis of 500 causes of death Slater found one or more inaccuracies in $29 \%$ of certificates, ${ }^{10}$ in line with previous findings. ${ }^{11}$ Comparison of these two papers is difficult: Slater views "a mode of dying" as unacceptable for inclusion in the cause of death, incorrectly citing recent guidance on completing death certificates published by the Office of Population Censuses and Surveys which, in fact, suggests only that a statement of mode of dying may be unacceptable if it is used alone on a medical certificate. ${ }^{12}$ Removing "mode of dying (qualified)" from Slater's analysis almost halves the proportion of inaccuracies to $14 \cdot 4 \%$-appreciably less than Leadbeatter's estimate that $27 \cdot 5 \%$ of 2085 causes of death were inaccurate. ${ }^{1}$ That study also showed that it might be unwise to rely on such inaccuracies being corrected by what Slater refers to as "expert intervention by the Registrar of Births and Deaths."

What can be done? A short term solution that we have adopted, arising from regular audits of deaths in hospital, is for one of us to scrutinise the case notes of all patients who die after admission to medical wards. This is then followed by discussion with junior doctors of the certification or reporting of those deaths. Although time consuming, this appears to help and is similar to practice in Finland, where all death certificates are scrutinised by the provincial forensic pathologist, who requests revision of unsatisfactory entries before the documents are forwarded to the registrar general. Cooperation between committed pathology and clinical staff may also influence the hospital necropsy rate. ${ }^{13}$

A national long term solution, however, requires both debate and reworking of all legislation concerning the dead. A coherent legislative framework is needed to address all activities relating to death. These include the definition, diagnosis, and certification of death; transplantation; the need for hospital postmortem examinations as a part of audit; the role of the present coroner system versus a "medical examiner" system; and the retention of postmortem material for research. Even were parliamentary time and will sufficient to allow such legislative change it would remain necessary to ensure that doctors received education - if not examinationin their medicolegal responsibilities.

STEPHEN LEADBEATTER Senior lecturer in forensic pathology BERNARD KNIGHT

Wales Institute of Forensic Medicine, Professor of forensic pathology

University of Wales College of Medicine,

Royal Infirmary,

Cardiff CF2 1SZ

I Start RD, Delargy-Aziz Y, Dorries CP, Silcocks PB, Cotton BWK. Clinicians and the coronial system: an assessment of the ability of clinicians to recognise reportable deaths. $B M \mathcal{F}$ system: an assess

2 Leadbeatter S, Knight B. Anomalies and ambiguities in the disposal of the dead. $f R$ Coll Physicians Lond 1986;20:273-5.

3 Knight B, McKim Thompson I. The teaching of legal medicine in British medical schools. $f$ Med Education 1986;20:246-58.

4 Knapman PA, Powers MJ. The law and practice on coroners. Chichester: Barry Rose, 1985.

$5 \mathrm{R} v$ Clerk '702 1 Salk 377.

6 Polson CJ, Marshall TK. The disposal of the dead. 3rd ed. London: English Universities Press, 1975.

$7 \mathrm{R} v$ Purcy and Others [1933]. All E R 630.

8 Births and Deaths Registration Act 1953. London: HMSO, 1953:s 22 (1).

9 Committee on Death Certification and Coroners. Report. London: HMSO, 1971. (Cmnd No 4810.) 10 Slater DN. Certifying the cause of death: an audit of wording inaccuracies. $f$ Clin Pathol 1993;46:232-4.

1. Leaderter S. Semantics of death certification. $\mathcal{F} R$ Coll Physicians Lond 1986;20:129-32.

12 Ashley JSA. Completion of medical certificates of cause of death. London: Office of Population Censuses and Surveys, 1990.

13 Champ C, Tyler X, Andrews PS, Coghill SB. Improve your hospital autopsy rate to 40-50 per cent, a tale of two towns. F Pathol 1992;166:405-7. 